\title{
Short-term absence from industry \\ II Temporal variation and inter-association with other recorded factors
}

\author{
P. FROGGATT \\ Department of Social and Preventive Medicine, The Queen's University, Belfast
}

Froggatt, P. (1970). Brit. J. industr. Med., 27, 211-224. Short-term absence from industry. II. Temporal variation and inter-association with other recorded factors. This paper $(a)$ extends the previous analysis (Froggatt, 1970b) of short-term absence from work among groups of male and female industrial personnel and clerks in government service, and $(b)$ studies other recorded variables, particularly lateness, long-term sickness absence, and passes from work both 'medical' and 'works'.

Multiple regression shows one-day absences to be generally associated with two-day absences, lateness, and medical passes but independent of works passes and long-term sickness absence; and two-day absences to be generally associated with one-day absences and long-term sickness absence but not with lateness or passes from work. Higher order correlations show lateness and works passes, medical passes and works passes, and lateness and age to be (weakly) associated, the last negatively.

Irrespective of season, one-day absences were consistently most prevalent on Monday and least so on Friday, with a subsidiary peak for the male groups on Wednesday; two-day absences - as measured by the day each absence starts - were consistently most prevalent on Monday and least so on Thursday (Friday was omitted) and during the summer months. Medical passes were generally independent of the day of the week and the period of the year; lateness was greatest on Friday and during the winter, though the increase was slight; but works passes were relatively prevalent on Friday.

Correlation and regression show the association between numbers of one-day absences taken in two periods of time (each one year) to be marked ( $r=0.5$ to 0.7$)$, unaffected by transforming to normal functions, and explicable on a linear hypothesis, but the value of $r$ to increase as the periods of time increase and to decrease as the interval between the periods of time lengthens. Similar analyses for two-day absences show $r=0.25$ to 0.55 , acceptance of a linear hypothesis, and a suggestion that the value of $r$ may increase as the periods of time increase and as the interval between them shortens. More limited examination shows corresponding values of $\mathrm{r}$ (for contiguous years) to be of the order 0.25 for medical passes, 0.60 for works passes, but $>0.80$ for lateness.

Values of $r$ between each of these factors in turn for all possible pairs of days of the week are reasonably consistent and show $r$ of the order 0.35 for one-day absences, $\mathbf{0 . 2 5}$ for medical passes, $\mathbf{0 . 4 0}$ for works passes, and $\mathbf{0 . 8 0}$ for lateness (values for two-day absences are irregular and in the range 0 to $0 \cdot 4$ ). The consistency of lateness experience over days and years is very marked, the correlations being among the highest recorded for any event involving human behaviour.

The importance and application of the findings are briefly discussed; detailed consideration is reserved for the third and last paper. 
In a previous paper (Froggatt, 1970b) I reviewed the literature, defined terms, described the material (from two engineering industries and two government departments), delimited 20 'study groups' on the basis of sex, marital status, supervisory grade, and employment status, and examined the effect of age and length of service on the numbers of one-day and two-day absences taken over varying periods of time. In this paper I examine (a) the association with short-term absence of lateness, long-term sickness absence, and passes from work; (b) the interrelationships between lateness, passes from work, age, and length of service; (c) the daily and seasonal variation in short-term absence, lateness, and passes from work; and $(d)$ the association between an individual's experience, of each of these variates in turn, in different periods of time. The results contribute to an understanding of the 'causes' of short-term absences and some are of practical importance. Since one-day and two-day absences are the factors principally under study, analyses involving them are more detailed than those involving exclusively the other variates. The extensive material has been compressed by presenting here mainly results based on groups from company $G$; results from company $M$ and the government departments are introduced for comparison. Unless otherwise stated, the periods of observation are as in the previous paper (Froggatt, 1970b), viz., 1957-58 for groups G1 to G8; $1955-58$ for groups G9 to G12; 1958-59 for groups M1 and M2; 1953-59 for groups M3 and M4; and 1959 for all SC groups. The information presented here is that considered to be the most informative: for complete figures and results see Froggatt (1967).

\section{Association of short-term absence with long-term sickness absence, lateness, and passes from work}

One-day absences: Groups G1 to G8

Multiple linear regression equations, as already described (Froggatt, 1970b), were derived for the number of one-day absences $\left(y_{1}\right)$ on the number of two-day absences $\left(y_{2}\right)$, lateness $\left(x_{3}\right)$ ('times late' for the works personnel groups G1 and G2; 'minutes late' for staff groups G3 to G8), passes from work $\left(x_{4}\right)$, and number of days of long-term (spells $\geqslant 3$ days) sickness absence $\left(x_{5}\right)$; for $G 3$ - technically the most suitable group - $x_{4}$ was split into $x_{4 m}$ (medical passes) and $\mathrm{x}_{4 \mathrm{~W}}$ (works passes). The partial regression coefficients are identified by corresponding suoscripts $b_{2}, b_{3}$, etc. Previous results (Froggatt, 1970b) indicated that reliability would be little improved by substituting the normally distributed variate $\sqrt{y_{1}}$ for the (skewed) absolute measure $y_{1}$; the latter, which is convenient to apply in practice, is therefore used. The independent variates are all 'positively' skewed: their means and standard deviations are in Table 1.

TABLE 1

Means ANd STANDARd DeVIations ( $\sigma$ ) For Lateness, Number of Passes from Work, AND LONG-TERM SiCKNESS ABSENCE, 1957-58

\begin{tabular}{|c|c|c|c|c|c|c|}
\hline \multirow[t]{2}{*}{ Group } & \multicolumn{2}{|c|}{ Lateness ${ }^{1}$} & \multicolumn{2}{|c|}{ All passes } & \multicolumn{2}{|c|}{$\begin{array}{c}\text { Long-term } \\
\text { sickness } \\
\text { absence (days) }\end{array}$} \\
\hline & Mean & $\boldsymbol{\sigma}$ & Mean & $\sigma$ & Mean & $\boldsymbol{\sigma}$ \\
\hline $\begin{array}{l}\text { G1 } \\
\text { G2 } \\
\text { G3 }\end{array}$ & $\begin{array}{r}22 \cdot 3 \\
16 \cdot 4 \\
293 \cdot 0\end{array}$ & $\begin{array}{r}29 \cdot 4 \\
25 \cdot 7 \\
361 \cdot 6\end{array}$ & $\begin{array}{l}6 \cdot 0 \\
3 \cdot 7 \\
2 \cdot 4^{2} \\
7 \cdot 9^{3}\end{array}$ & $\begin{array}{l}4.6 \\
3.8 \\
2 \cdot 8 \\
6.7\end{array}$ & $\begin{array}{r}5 \cdot 2 \\
7 \cdot 2 \\
14.9\end{array}$ & $\begin{array}{l}12 \cdot 4 \\
12 \cdot 8 \\
20 \cdot 0\end{array}$ \\
\hline $\begin{array}{l}\text { G4 } \\
\text { G5 } \\
\text { G6 } \\
\text { G7 } \\
\text { G8 }\end{array}$ & $\begin{array}{l}610 \cdot 3 \\
220 \cdot 0 \\
414 \cdot 2 \\
202 \cdot 0 \\
151 \cdot 7\end{array}$ & $\begin{array}{l}679 \cdot 5 \\
357 \cdot 8 \\
428 \cdot 3 \\
279 \cdot 8 \\
247 \cdot 3\end{array}$ & $\begin{array}{r}13.2 \\
6.8 \\
9.6 \\
10.8 \\
7.1\end{array}$ & $\begin{array}{l}9.9 \\
6 \cdot 0 \\
9 \cdot 2 \\
8 \cdot 8 \\
5.8\end{array}$ & $\begin{array}{r}12 \cdot 3 \\
9 \cdot 7 \\
9 \cdot 2 \\
10 \cdot 7 \\
11 \cdot 4\end{array}$ & $\begin{array}{l}16 \cdot 8 \\
14 \cdot 5 \\
16 \cdot 5 \\
14 \cdot 8 \\
17 \cdot 4\end{array}$ \\
\hline
\end{tabular}

1'Times late' for G1 and G2; 'minutes late' for others. ${ }^{2}$ Medical passes. $\quad{ }^{3}$ Works passes.

In each group the significant and non-significant regression terms were parcelled out and, after showing (by analysis of variance) that in no group did the latter when taken together contribute significantly to the prediction of one-day absences, the equations were re-calculated using only the significant terms (Table 2). These regressions account for between $15 \%$ (in G4) and $41 \%$ (in G3) of the total variation in $\mathrm{y}_{1}$.

\section{Two-day absences: Groups G1 to G8}

Regression equations were derived as before after transposing $y_{1}$ and $y_{2}$, the latter now becoming the dependent variate. Parcelling out the significant and non-significant terms and testing as for one-day absences leads to re-calculated equations using only the significant terms (Table 3). These regressions account for between $6 \%$ (in G4) and $31 \%$ (in G1 and G3) of the total variation in $y_{2}$.

\section{Interrelationships between lateness, passes from work, age, and length of service}

In (staff) group G3 - technically the most suitable study group for this analysis - partial correlation between lateness $\left(x_{3}\right)$, number of medical passes $\left(x_{4 m}\right)$, and number of works passes $\left(x_{4 \mathrm{w}}\right)$ gave:

$$
\begin{aligned}
& r\left(x_{3} x_{4 m} \cdot x_{4 w}\right)=0.105(0.20>P>0.10) \\
& r\left(x_{3} x_{4} w \cdot x_{4 m}\right)=0.190(0.05>P>0.02) \\
& r\left(x_{4 m} x_{4 w} \cdot x_{3}\right)=0.232(0.02>P>0.01)
\end{aligned}
$$


TABLE 2

Multiple Regression Equations for the Predicted Mean Number of One-day Absences (Y $\left.\mathbf{Y}_{1}\right)$ GIVEN $y_{2}, x_{3} \ldots \ldots$, , AFTER OMITTING NON-SIGNIFICANT TERMS

\begin{tabular}{|c|c|c|c|c|c|}
\hline \multirow{2}{*}{ Group } & \multicolumn{5}{|c|}{ Estimates $^{1} \pm$ standard errors (data for 1957-58) } \\
\hline & c & $b_{2}$ & & $\mathbf{b}_{3}$ & $\mathbf{b}_{4}$ \\
\hline $\begin{array}{l}\text { G1 } \\
\text { G2 } \\
\text { G3 } \\
\text { G4 } \\
\text { G5 } \\
\text { G6 } \\
\text { G7 } \\
\text { G8 }\end{array}$ & $\begin{array}{l}2 \cdot 830 \\
1 \cdot 960 \\
2 \cdot 664 \\
3 \cdot 555 \\
2 \cdot 739 \\
2 \cdot 734 \\
3 \cdot 636 \\
2 \cdot 482\end{array}$ & $\begin{array}{r}1 \cdot 170 \pm 0.220 \\
1.286 \pm 0.264 \\
1.245 \pm 0.214 \\
\pm=0.370 \pm 0.148 \\
\overline{0.703 \pm 0.182} \\
0.902 \pm 0.210\end{array}$ & $\begin{array}{l}0.046 \\
0.047 \\
0.004 \\
0.0014 \\
0.004 \\
0.005 \\
0.005 \\
0.004\end{array}$ & $\begin{array}{l} \pm 0.012 \\
\pm 0.011 \\
\pm 0.001 \\
\pm 0.0004 \\
\pm 0.001 \\
\pm 0.001 \\
\pm 0.001 \\
\pm 0.001\end{array}$ & $\begin{array}{c}\overline{-} \\
\mathrm{b}_{\mathrm{4m}}= \\
0.30 \pm 0.14 \\
0.093 \pm 0.027 \\
\overline{0} \\
0.116 \pm 0.048 \\
-\end{array}$ \\
\hline
\end{tabular}

${ }^{1}$ All coefficients are significant; for their associated variates see text.

i.e., weak but significant (on normal theory) associations between lateness and works passes with medical passes held constant, and works passes and medical passes with lateness held constant. Extending the examination to include age $\left(\mathrm{x}_{1}\right)$ and length of service $\left(x_{2}\right)$ gives a series of first-order partial correlation coefficients only one of which - lateness with age holding length of service constant - is significant

$$
\text { ( } \left.r \text { for } \mathrm{x}_{3} \mathrm{x}_{1} \cdot \mathrm{x}_{2}=-0.230,0.02>\mathrm{P}>0.01\right) \text {. }
$$

(The comparatively small inter-correlations between $x_{3}, x_{4 w}$, and $x_{4 m}$ above indicate that higher-order coefficients would differ little from these first-order results.) This negative correlation between lateness and age independent of length of service is in fact even weaker for works personnel (in group G1, $r$ for $x_{3} x_{1} \cdot x_{2}=-0.150,0 \cdot 20>P>0 \cdot 10$ ). As a general conclusion we may say that the interassociations are in practice unimportant; but too much emphasis should not be placed on the precise probability levels of the coefficients as many of the generating distributions are highly skewed and tests based on normal theory are therefore strictly inapplicable.

\section{Daily and seasonal variations in short-term absence, lateness, and passes from work}

It has long been known that morbidity fluctuates seasonally (Select Committee, 1825, appendix B9; Guy, 1843; Departmental Committee, 1907, First Report, Pt. II, App. C; Watson, 1927) and that attendance at work is unevenly distributed over the days of the week - Monday and the days bracketing holidays showing the highest absence (Departmental Committee, 1907, Final Report, Pt. I, p. 16; Pt. II, QQ 8742,10552 - 8; Munition Workers Committee, 1917-8; Ministry of Fuel and Power, 1948-9, Table 15; Buzzard and Liddell, 1963; see also

TABLE 3

Multiple Regression Equations for the Predicted Mean Number of Two-day Absences $\left(y_{2}\right)$ given $\mathbf{Y}_{1}, \mathbf{x}_{3} \ldots \ldots$, AFTER OMITTING NON-SIGNIFICANT TERMS

\begin{tabular}{|c|c|c|c|c|}
\hline \multirow{2}{*}{ Group } & \multicolumn{4}{|c|}{ Estimates $^{1} \pm$ standard errors (data for $1957-58$ ) } \\
\hline & c & $b_{1}$ & $b_{3}$ & $b_{5}$ \\
\hline $\begin{array}{l}\text { G1 } \\
\text { G2 } \\
\text { G3 } \\
\text { G4 } \\
\text { G5 } \\
\text { G6 } \\
\text { G7 } \\
\text { G8 }\end{array}$ & $\begin{array}{r}-0.066 \\
0.090 \\
0.912 \\
1.833 \\
1.132 \\
1.041 \\
0.619 \\
0.884\end{array}$ & $\begin{array}{l}0.169 \pm 0.029 \\
0.112 \pm 0.025 \\
0.199 \pm 0.028 \\
\pm= \\
0.126 \pm 0.050 \\
0.167 \pm 0.041 \\
0.159 \pm 0.037\end{array}$ & $\begin{array}{c}- \\
\text { - } \\
0.0006 \pm 0.0002 \\
0.0012 \pm 0.0005 \\
0.002 \pm 0.001 \\
=\end{array}$ & $\begin{array}{c}0.031 \pm 0.011 \\
0.015 \pm 0.007 \\
= \\
= \\
0.036 \pm 0.012 \\
0.024 \pm 0.011 \\
0.016 \pm 0.008\end{array}$ \\
\hline
\end{tabular}

${ }^{1}$ All coefficients are significant; for their associated variates see text. 
Froggatt, 1970b, for sources). Daily variation also occurs in the day sickness spells start, Monday again having the highest incidence (Hill, 1929; Wyatt et al., 1943; Gordon et al., 1959; Taylor, 1967a) - though there may be maxima on other days of the week, for example, shift workers (Taylor, 1967a) - and this applies even to absences of one or two days' duration (Hart, 1922). Daily variation is important because it has a disproportionately disruptive effect on industrial efficiency and it has been studied by Behrend (1951, 1959; Baldamus and Behrend, 1950), who devised the 'blue Monday' index, and by Liddell (1954a), who developed the more flexible 'index of dispersal'.

Material for analysis was obtained mainly from groups G1 to G8 and SC3 and SC4, two-day absences starting on Friday (which by definition include the following Monday) being omitted. The null hypothesis that for each group there is no difference between the respective numbers of one-day absences taken, and two-day absences starting, on each day of the working week was tested using $\chi^{2}$ and then re-tested after omitting all one-day absences on Monday and Friday, and all two-day absences starting on Monday and Thursday, since these may have been part of longer episodes. Inter-group differences in, respectively, the numbers of one-day and two-day absences by day of the week were examined by comparing the distributions of such absences between groups within days of the week. This method ignores the effect on one-day absences of known group differences in age structure; the association, however, between age and number of one-day absences has been shown to be very weak (Froggatt, 1970b) and furthermore the alternative of covariance analysis is strictly not applicable since, when the mandatory normally distributed variate $\sqrt{ } y_{1}$ was used, the eight regressions of $\sqrt{ } y_{1}$ on $x_{1}$ for groups G1 to G8 were not parallel (Froggatt, 1970b).

'Seasonal' variation of short-term absences was examined, as for daily variation above, for periods A (January to April), B (May to August), and C (September to December) after adjustment for differences in 'exposure' due to $(a)$ holiday periods and $(b)$ the disproportionate winter prevalence of long-term sickness absence as follows. As regards (a), holidays during periods $\mathrm{A}, \mathrm{B}$, and $\mathrm{C}$ were respectively 2,12 , and 4 working days: days of exposure were therefore in the (approximate) ratio A : B : C = 1.0 : 0.92:0.99 and 'adjustment' obtained by multiplying the numbers of one-day and two-day absences during periods $B$ and $C$ by respectively 1.09 and 1.01 , the results being expressed to the nearest integer. As regards $(b)$, for one-day absences groups G1 to G8, already restricted to employees with less than 65 days' total absence in either 1957 or 1958, were further truncated by omitting personnel with more than 10 working days' certified absence (an arbitrary figure) over 1957-58: this strictness was necessary because frequency of certified absence varies with the day of the week (Hill, 1929). The remainder - the 'truncated' groups - are considered to be representative of the whole (with respect to one-day absences) since we have already shown that numbers of one-day absences and of days of long-term sickness absence are independent. For two-day absences groups $\mathrm{G} 1$ to G8 were not truncated because of the demonstrated association between this variable and long-term sickness absence (Table 3).

\section{One-day absences}

Day of the week Table 4 shows that one-day absences were unequally distributed over the week; in each group Monday had the most and Friday the least absence with subsidiary peaks on Wednesday (for males) and Thursday (for females, G8). This held also for government clerks (SC3 and SC4) though without the Wednesday peak for males. The variables which classify the male groups G1 to G7, viz., marital status, supervisory grade, employment class, and method of payment, had no gross effects on the experience even though $\chi^{2}$ for heterogeneity is significant; and for females the daily frequencies among the married and single in group G8 were not significantly different $\left(\chi^{2}=4 \cdot 105, \quad\right.$ D.F. $=4$, $0.50>P>0.30$ ). Testing showed that the daily pattern was generally independent of the total number of one-day absences an individual took (Froggatt, 1967, Table VI.4), a result unlikely to be affected by marked personal preference for any particular day since the correlations between the numbers of day-of-the-week-specific one-day absences taken by the same individuals in 1957 and 1958 were very weak ( $r$ in the range $0 \cdot 10$ to $0 \cdot 25$ ).

One-day absences on Monday and Friday were then omitted and re-testing the remaining frequencies in Table 4 showed rejection of the null hypothesis in only four groups $(G 3,4,5$, and 7) but the intergroup experience was not dissimilar ( $\chi^{2}$ for heterogeneity $(G 1$ to $G 7)=17 \cdot 29, \quad$ D.F. $=12$, $0 \cdot 20>P>0 \cdot 10$ ).

The consistent subsidiary Wednesday peak for males in company $\mathrm{G}$ suggests two hypotheses: (a) that it is connected with mid-week activities, mainly sport (this is strengthened by the fact that no peak is evident for women), and (b) that it was due to Christmas Eve (in 1958) and the eve of the Twelfth of July holidays (in 1957) falling on a Wednesday, the day preceding short holidays being notorious for bad attendance. As regards $(a)$, the distribution of one-day absences by day of the week within each period of the year (A, B, and C) among the 124 members of the 'truncated' (see above) group G4 showed that the null hypothesis of inter-group 
TABLE 4

Frequencies (and Percentages) of One-day Absences by Day of the Week

\begin{tabular}{|c|c|c|c|c|c|c|}
\hline Group & Monday & Tuesday & Wednesday & Thursday & Friday & $\left(\text { D.F. }{ }^{x^{2}}=4\right)^{1}$ \\
\hline G1 & $\begin{array}{c}151 \\
(27 \cdot 0)\end{array}$ & $\begin{array}{c}116 \\
(20 \cdot 8)\end{array}$ & $\begin{array}{l}121 \\
(21 \cdot 7)\end{array}$ & $\begin{array}{c}107 \\
(19 \cdot 1)\end{array}$ & 64 & $35 \cdot 30$ \\
\hline G2 & 118 & 87 & 100 & 70 & 54 & $29 \cdot 15$ \\
\hline & $(27.5)$ & $(20 \cdot 3)$ & $(23 \cdot 3)$ & (16.3) & (12.6) & \\
\hline G3 & $\begin{array}{c}258 \\
(29 \cdot 2)\end{array}$ & 192 & 211 & 163 & 61 & $121 \cdot 97$ \\
\hline G4 & 292 & $\begin{array}{c}(21 \cdot 7) \\
251\end{array}$ & $\begin{array}{c}(23 \cdot 8) \\
287\end{array}$ & $\begin{array}{c}(18.4) \\
210\end{array}$ & $\begin{array}{l}(6 \cdot 9) \\
65\end{array}$ & 158.55 \\
\hline & $(26 \cdot 4)$ & $(22 \cdot 7)$ & $(26 \cdot 0)$ & $(19 \cdot 0)$ & (5.9) & \\
\hline G5 & 174 & 105 & 136 & 102 & 64 & $58 \cdot 39$ \\
\hline & $\begin{array}{l}(30.0) \\
150\end{array}$ & $(18 \cdot 1)$ & $(23 \cdot 4)$ & (17.6) & $(11 \cdot 0)$ & \\
\hline G6 & $\begin{array}{c}159 \\
(29 \cdot 7)\end{array}$ & 114 & 120 & 91 & 52 & 57.86 \\
\hline & $\begin{array}{c}(29 \cdot 7) \\
166\end{array}$ & $(21 \cdot 3)$ & $(22 \cdot 4)$ & $(17 \cdot 0$ & (9.7) & \\
\hline $\mathbf{J}$ & $\begin{array}{c}166 \\
(25 \cdot 6)\end{array}$ & $\begin{array}{c}151 \\
(23 \cdot 3)\end{array}$ & $\begin{array}{c}187 \\
(28 \cdot 8)\end{array}$ & $\begin{array}{c}112 \\
(17 \cdot 3)\end{array}$ & $\begin{array}{l}33 \\
(5 \cdot 1)\end{array}$ & $113 \cdot 38$ \\
\hline G8 & $\begin{array}{c}134 \\
(26 \cdot 8)\end{array}$ & $\begin{array}{c}84 \\
(16 \cdot 8)\end{array}$ & $\begin{array}{c}94 \\
(18.8)\end{array}$ & $\begin{array}{l}118 \\
(23 \cdot 6)\end{array}$ & 70 & $26 \cdot 72$ \\
\hline Total & $\begin{array}{c}1,452 \\
(27 \cdot 7)\end{array}$ & $\begin{array}{l}1,100 \\
(21 \cdot 0)\end{array}$ & $\begin{array}{c}1,256 \\
(24 \cdot 0)\end{array}$ & $\begin{array}{c}973 \\
(18 \cdot 6)\end{array}$ & $\begin{array}{l}463 \\
(8 \cdot 8)\end{array}$ & - \\
\hline
\end{tabular}

${ }^{1 P}<0.001$ throughout.

$x^{2}$ for heterogeneity $(\mathrm{G} 1$ to G7) $=43.40$, D.F. $=24,0.01>P>0.001$.

homogeneity could not be rejected $\left(\chi^{2}=8.951\right.$, D.F. $=8,0.50>P>0.30$ ) which suggested that excessive Wednesday absence was not ascribable to seasonal mid-week activities. To examine $(b)$, the frequencies of one-day absences by day of the week were examined in groups G9 to G12 (over the four years of these data any effects due to a holiday eve would not bear on a single day of the week) but the subsidiary peak on Wednesday persisted. The convenience of an occasional mid-week 'day-off' seems a reasonable interpretation in an industry traditionally used to a six-day week and might explain its absence among government clerks.

Period of the year Seasonal variation in one-day absences was examined in groups G1 to G8 'truncated' (for certified absence) and 'adjusted' (for seasonal holidays), both as described above, by testing the null hypothesis that the number of oneday absences is independent of the period (A, B, and C) of the year. Table 5 shows that the hypothesis need not be rejected in any group and that there is no significant heterogeneity between the groups' experience.

Consistency of one-day absence by day of the week The correlation coefficients ( $r$ ) for the number of one-day absences taken on all possible pairs of days of the week for groups G2 (works personnel) and G3 and G4 (weekly-paid staff) are everywhere positive, though generally small (only 3 out of 30 are greater than $0 \cdot 4$ ), and there seems no consistent pattern in their comparative values within groups (Table 6). The skewness of the generating distributions dictates caution in interpretation.

\section{Two-day absences}

Day of the week Proceeding as for one-day absences, Table 7 shows that the number of two-day absences (i.e., the day on which a two-day absence starts) varied with the day of the week and that there was no significant inter-group heterogeneity in the results. Monday had everywhere the highest proportion while for males (G1 to G7) the frequency dropped as the week advanced though for females (G8) the nadir was mid-week. Results for male (SC3) and female (SC4) government clerks are similar to those for the male groups G1 to G7. Testing as for one-day absences again showed that the unequal daily frequencies were independent of the total number of two-day absences an individual took (Froggatt, 1967, Table VI.9).

Period of the year Again proceeding as for one-day absences - this time on groups G1 to G8 'adjusted' (for holidays) but not 'truncated' (for certified absences) - Table 8 shows that the null hypothesis can be rejected in six of the groups (and also on the total frequencies), period B (May to August) having generally the least number of two-day absences. These results are different from those for one-day absences which were independent of season. 
TABLE 5

Frequencies (and Percentages) of 'Adjusted’11 Number of One-day Absences by Period of the Year

\begin{tabular}{|c|c|c|c|c|}
\hline \multirow{2}{*}{$\begin{array}{c}\text { 'Truncated' } \\
\text { group } 1\end{array}$} & \multicolumn{3}{|c|}{ Period } & \multirow{2}{*}{$($ D.F. $=2)$} \\
\hline & $\underset{(\text { Jan. }- \text { Apr. })}{\mathbf{A}}$ & $\underset{(M a y-A u g .)}{\text { B }}$ & $\underset{(\text { Sept.-Dec.) }}{\mathrm{C}}$ & \\
\hline G1 & 162 & 174 & 175 & $\begin{array}{l}0.56 \\
0.80\end{array}$ \\
\hline G2 & 117 & 90 & 106 & 3.54 \\
\hline & $(37 \cdot 4)$ & $(28 \cdot 8)$ & (33.9) & $0.20>P>0.10$ \\
\hline G3 & 175 & 164 & 175 & 0.47 \\
\hline$C_{1}$ & $\begin{array}{c}(34 \cdot 0) \\
238\end{array}$ & $(32 \cdot 0)$ & $(34 \cdot 0)$ & $0.80>P>0.70$ \\
\hline G4 & $\begin{array}{c}238 \\
(33 \cdot 7)\end{array}$ & $\begin{array}{c}224 \\
(31 \cdot 7)\end{array}$ & $\begin{array}{c}244 \\
(34 \cdot 6)\end{array}$ & $\begin{array}{c}0.90 \\
0.70>P>0.50\end{array}$ \\
\hline G5 & 173 & 160 & 133 & $5 \cdot 36$ \\
\hline & $(37 \cdot 1)$ & $(34 \cdot 3)$ & $(28 \cdot 5)$ & $0.10>P>0.05$ \\
\hline G6 & 108 & 113 & 115 & 0.23 \\
\hline & $(32 \cdot 1)$ & $(33 \cdot 6)$ & $(34 \cdot 2)$ & $0.90>P>0.80$ \\
\hline G7 & 150 & 136 & 129 & 1.65 \\
\hline & $(36 \cdot 1)$ & $(32 \cdot 8)$ & $(31 \cdot 1)$ & $0.50>P>0.30$ \\
\hline G8 & $\begin{array}{c}97 \\
(33 \cdot 3)\end{array}$ & $\begin{array}{c}98 \\
(33 \cdot 3)\end{array}$ & $\begin{array}{c}98 \\
(33 \cdot 3)\end{array}$ & $\begin{array}{c}0.01 \\
P>0.99\end{array}$ \\
\hline Total & $\begin{array}{l}1,220 \\
(34 \cdot 3)\end{array}$ & $\begin{array}{c}1,159 \\
(32 \cdot 6)\end{array}$ & $\begin{array}{l}1,175 \\
(33 \cdot 0)\end{array}$ & - \\
\hline
\end{tabular}

${ }^{1}$ As defined in the text.

$x^{2}$ for heterogeneity $=11.02$, D.F. $=14,0.70>P>0.50$.

Consistency of two-day absences by day of the week This was measured as for one-day absences though, because of the very low annual mean number of two-day absences, only on the largest group over the longest possible period (G12 over 1955-58). The values of $r$ are positive though those involving Thursday are insignificant (Table 6, last column).

\section{TABLE 6}

CORRELATION COEFFICIENTS (r) BETWEEN RESPECTIVELY THE NUMBERS OF ONE-DAY AND TWO-DAY ABSENCES BY DAY OF THE WEEK

\begin{tabular}{l|ccc|c}
\hline \multirow{2}{*}{ Day of the week } & \multicolumn{3}{|c|}{ One-day absences } & $\begin{array}{c}\text { Two-day } \\
\text { absences }\end{array}$ \\
\cline { 2 - 5 } & G2 & G3 & G4 & G4 \\
\hline Mon./Tues. & 0.322 & 0.343 & 0.308 & 0.326 \\
Mon./Wed. & 0.253 & 0.345 & 0.276 & 0.410 \\
Mon./Thurs. & 0.339 & 0.245 & 0.082 & -0.090 \\
Mon./Fri. & 0.236 & 0.296 & 0.144 & - \\
Tues./Wed. & 0.399 & 0.217 & 0.307 & 0.455 \\
Tues./Thurs. & 0.301 & 0.268 & 0.273 & $\mathbf{0 . 0 3 2}$ \\
Tues/Fri. & 0.252 & 0.117 & 0.065 & - \\
Wed./Thurs. & 0.480 & 0.348 & 0.360 & 0.038 \\
Wed./Fri. & 0.410 & 0.343 & 0.112 & - \\
Thurs./Fri. & 0.384 & 0.421 & 0.050 & - \\
& & & & \\
\hline
\end{tabular}

Approximate standard errors are 0.09 in $\mathrm{G} 2$ and $\mathrm{G} 3$, and 0.07 in $\mathrm{G} 4$.
The skewness of the generating distributions again dictates caution in interpretation.

\section{Lateness and passes from work}

Proceeding as for short-term absence above, results from group G3 - in which medical and works passes were distinguished - show (Table 9) that the null hypothesis of equal frequencies by day of the week and by period of the year can be rejected for lateness and works passes but not for medical passes. (Lateness for this group was abstracted as 'minutes late' - rather than the preferable statistic 'occasions late' - which is very susceptible to aberration and also small proportional differences may be significant even though in practice unimportant.) Inspection shows greatest lateness on Friday and in period C (September to December), greatest number of works passes on Friday and medical passes on Monday, and greatest number of passes of each type in period $B$.

Group G3 comprises exclusively junior married males and, to see if the findings by day of the week held more generally, information was collected from 46 junior single females from one centre over 1957-58 and 72 junior single males from another centre over 1958 , these persons fulfilling the strict selection criteria adopted for the study groups (Froggatt, $1970 \mathrm{~b}$ ). The results (Table 10) generally confirm the previous findings except that, unlike males, females show a marked Friday peak for medical passes. 
TABLE 7

Frequencies (and Percentages) of Two-day Absences by Day of the Week

\begin{tabular}{|c|c|c|c|c|c|}
\hline Group & Monday & Tuesday & Wednesday & Thursday & $\begin{array}{c}x^{2} \\
(D \cdot F .=3)\end{array}$ \\
\hline G1 & 42 & 26 & 15 & 22 & 14.96 \\
\hline G2 & $\begin{array}{c}(40 \cdot 0) \\
28\end{array}$ & $\begin{array}{c}(24 \cdot 8) \\
19\end{array}$ & $\begin{array}{c}(14 \cdot 3) \\
17\end{array}$ & $\begin{array}{c}(21 \cdot 0) \\
7\end{array}$ & $\begin{array}{c}0.01>\underset{12.55}{P}>0.001 \\
\end{array}$ \\
\hline & $(39 \cdot 4)$ & $(26 \cdot 8)$ & $(23 \cdot 9)$ & $(9 \cdot 9)$ & $0.01>P>0.001$ \\
\hline G3 & 105 & 73 & 62 & 38 & $33 \cdot 40$ \\
\hline & $(37 \cdot 8)$ & $(26 \cdot 3)$ & $(72 \cdot 3)$ & $(13 \cdot 7)$ & $P<0.001$ \\
\hline G4 & 171 & 131 & 90 & 35 & 95.03 \\
\hline & $(40 \cdot 0)$ & $(30 \cdot 7)$ & $(21 \cdot 1)$ & $(8 \cdot 2)$ & $P<0.001$ \\
\hline G5 & 98 & 63 & 57 & 39 & 28.49 \\
\hline & $(38 \cdot 1)$ & $(24 \cdot 5)$ & $(22 \cdot 2)$ & $(15 \cdot 2)$ & $P<0.001$ \\
\hline G6 & 71 & 52 & 42 & 31 & $17 \cdot 67$ \\
\hline & $(36 \cdot 2)$ & $(26 \cdot 5)$ & $(21 \cdot 4)$ & $(15 \cdot 8)$ & $P<0.001$ \\
\hline G7 & 81 & 62 & 38 & 22 & 40.02 \\
\hline & $(39 \cdot 9)$ & $(30 \cdot 5)$ & $(18 \cdot 7)$ & $(10 \cdot 8)$ & $P<0.001$ \\
\hline G8 & 84 & 33 & 33 & 43 & $36 \cdot 70$ \\
\hline & $(43 \cdot 5)$ & $(17 \cdot 1)$ & $(17 \cdot 1)$ & $(22 \cdot 3)$ & $\mathrm{P}<0.001$ \\
\hline Total & $\begin{array}{c}680 \\
(39 \cdot 3)\end{array}$ & $\begin{array}{c}459 \\
(26.5)\end{array}$ & $\begin{array}{c}354 \\
(20 \cdot 5)\end{array}$ & $\begin{array}{c}237 \\
(13 \cdot 7)\end{array}$ & 一 \\
\hline
\end{tabular}

$x^{2}$ for heterogeneity $(\mathrm{G} 1$ to $\mathrm{G} 7)=16 \cdot 29, \mathrm{D} . \mathrm{F} .=18,0.70>\mathrm{P}>0.50$

TABLE 8

Frequencies (and Percentages) of 'Adjusted’1 Number of Two-day Absences by Period OF THE YEAR

\begin{tabular}{|c|c|c|c|c|}
\hline \multirow{2}{*}{ Group } & \multicolumn{3}{|c|}{ Period } & \multirow{2}{*}{$($ D.F. $=2)$} \\
\hline & $\underset{(\text { Jan.-Apr. })}{\mathbf{A}}$ & $\begin{array}{c}\text { B } \\
(\text { May-Aug. })\end{array}$ & $\begin{array}{c}\mathrm{C} \\
(\text { Sept. } . \text { Dec. })\end{array}$ & \\
\hline G1 & 39 & 23 & 45 & $7 \cdot 25$ \\
\hline & $(36 \cdot 5)$ & $(21 \cdot 5)$ & $(42 \cdot 1)$ & $0.05>P>0.02$ \\
\hline G2 & 20 & 24 & 30 & 2.05 \\
\hline & $(27 \cdot 0)$ & $(32 \cdot 4)$ & $(40 \cdot 5)$ & $0.50>P>0.30$ \\
\hline G3 & 116 & 67 & 105 & 13.77 \\
\hline & $(40 \cdot 3)$ & $(23 \cdot 3)$ & $(36 \cdot 5)$ & $0.01>P>0.001$ \\
\hline G4 & 138 & 124 & 175 & $9 \cdot 53$ \\
\hline & $(31 \cdot 6)$ & $(28 \cdot 4)$ & $(40 \cdot 0)$ & $0.01>\mathrm{P}>0.001$ \\
\hline G5 & 114 & 67 & 83 & $12 \cdot 98$ \\
\hline O & $(43 \cdot 2)$ & $(25 \cdot 4)$ & $(31 \cdot 4)$ & $0.01>P>0.001$ \\
\hline G6 & 82 & 44 & 75 & $12 \cdot 21$ \\
\hline G7 & $\begin{array}{c}(40 \cdot 8) \\
76\end{array}$ & $\begin{array}{c}(21 \cdot 9) \\
57\end{array}$ & $(37 \cdot 3)$ & $0.01>\underset{3.82}{P}>0.001$ \\
\hline 4 & $(36 \cdot 0)$ & $(27 \cdot 0)$ & $(37 \cdot 0)$ & $0.20>P>0.10$ \\
\hline G8 & 71 & 46 & 81 & $9 \cdot 85$ \\
\hline & $(35 \cdot 9)$ & $(23 \cdot 2)$ & $(40 \cdot 9)$ & $0.01>P>0.001$ \\
\hline Total & $\begin{array}{c}656 \\
(36 \cdot 9)\end{array}$ & $\begin{array}{c}452 \\
(25 \cdot 4)\end{array}$ & $\begin{array}{c}672 \\
(37 \cdot 8)\end{array}$ & \\
\hline
\end{tabular}

${ }^{1}$ As defined in the text.

$x^{2}$ for heterogeneity $=20 \cdot 82$, D.F. $=14,0.20>P>0 \cdot 10$.

The Friday peak for works passes is universal and, with the low one-day absence frequency on Friday (Tab!e 4), suggests that a premature start to the week-end manifests itself through sanctioned early leaving rather than complete absence on Friday.
Again too much should not be read into the results, especially those for lateness, because they are unduly sensitive to the disproportionate effect of a few aberrant experiences.

Consistency of each variate in turn by day of the 
TABLE 9

Lateness, Medical Passes, and Works Passes (and Percentages) by Day of the Week and Period of the Year (Group G3, 1957-58)

\begin{tabular}{|c|c|c|c|c|c|c|c|c|c|}
\hline \multirow{2}{*}{\multicolumn{4}{|c|}{ Variate }} & \multicolumn{5}{|c|}{ Day of the week } & \multirow{2}{*}{$(D . F .=4)$} \\
\hline & & & & \multirow{2}{*}{$\begin{array}{c}\text { Monday } \\
6152 \\
(18 \cdot 2) \\
67 \\
(24 \cdot 6) \\
192 \\
(20 \cdot 9)\end{array}$} & \multirow{2}{*}{$\begin{array}{c}\text { Tuesday } \\
6404 \\
(18 \cdot 9) \\
53 \\
(19 \cdot 5) \\
152 \\
(16 \cdot 6)\end{array}$} & \multirow{2}{*}{$\begin{array}{c}\text { Wednesday } \\
7203 \\
(21 \cdot 3) \\
44 \\
(16 \cdot 2) \\
189 \\
(20 \cdot 6)\end{array}$} & \multirow{2}{*}{$\begin{array}{c}\text { Thursday } \\
6654 \\
(19 \cdot 7) \\
54 \\
(19 \cdot 9) \\
143 \\
(15 \cdot 6)\end{array}$} & \multirow{2}{*}{$\begin{array}{c}\text { Friday } \\
7411 \\
(21 \cdot 9) \\
54 \\
(19 \cdot 9) \\
241 \\
(26 \cdot 3)\end{array}$} & \\
\hline $\begin{array}{l}\text { Lateness } \\
\text { (minutes) } \\
\text { Medical passes } \\
\text { Works passes }\end{array}$ & $\begin{array}{l}\cdots \\
\cdots \\
\cdots\end{array}$ & $\begin{array}{l}. \\
\ldots\end{array}$ & $\begin{array}{l}\cdots \\
\cdots \\
\cdots\end{array}$ & & & & & & $\begin{array}{c}166.68 \\
P<0.001 \\
4.95 \\
0.30>P>0.20 \\
32.94 \\
P<0.001\end{array}$ \\
\hline \multirow{2}{*}{\multicolumn{4}{|c|}{ Variate $^{1}$}} & \multicolumn{5}{|c|}{ Period of the year } & \multirow{2}{*}{$\left.\stackrel{x^{2}}{(D . F .}=2\right)$} \\
\hline & & & & \multicolumn{2}{|c|}{$\underset{(J a n .-A p r .)}{A}$} & $\begin{array}{c}\text { B } \\
(M a y-A u g .)\end{array}$ & \multicolumn{2}{|c|}{$\begin{array}{c}\mathrm{C} \\
(\text { Sept.-Dec.) }\end{array}$} & \\
\hline $\begin{array}{l}\text { Lateness } \\
\text { (minutes) } \\
\text { Medical passes } \\
\text { Works passes }\end{array}$ & $\begin{array}{l}\cdots \\
\cdots \\
\cdots\end{array}$ & . & .. & \multicolumn{2}{|c|}{$\begin{array}{c}11,140 \\
(31 \cdot 9) \\
98 \\
(34 \cdot 8) \\
235 \\
(24 \cdot 7)\end{array}$} & $\begin{array}{c}11,229 \\
(32 \cdot 2) \\
107 \\
(37 \cdot 9) \\
375 \\
(39 \cdot 4)\end{array}$ & \multicolumn{2}{|c|}{$\begin{array}{c}12,506 \\
(35 \cdot 9) \\
77 \\
(27 \cdot 3) \\
342 \\
(35 \cdot 9)\end{array}$} & $\begin{array}{c}100.49 \\
P<0.001 \\
5.04 \\
0.10>P>0.05 \\
33.76 \\
P<0.001\end{array}$ \\
\hline
\end{tabular}

1'Adjusted' for season as defined in text.

TABLE 10

Lateness, Medical Passes, and Works Passes (and Percentages) by Day of the Week for Groups of Junior Single Females and Junior Single Males

\begin{tabular}{|c|c|c|c|c|c|c|c|}
\hline \multirow{2}{*}{ Variate } & & \multicolumn{5}{|c|}{ Day of the week } & \multirow{2}{*}{$($ D.F. $=4)$} \\
\hline & & Monday & Tuesday & Wednesday & Thursday & Friday & \\
\hline $\begin{array}{l}46 \text { JSF staff, 1957-58 } \\
\text { Lateness (minutes) } \\
\text { Medical passes } \ldots \\
\text { Works passes } \quad \ldots\end{array}$ & $\begin{array}{l}\cdots \\
\ldots \\
\ldots\end{array}$ & $\begin{array}{r}1124 \\
(19 \cdot 4) \\
14 \\
(17 \cdot 1) \\
28 \\
(15 \cdot 7)\end{array}$ & $\begin{array}{c}1058 \\
(18 \cdot 3) \\
15 \\
(18 \cdot 3) \\
23 \\
(12 \cdot 9)\end{array}$ & $\begin{array}{r}1183 \\
(20 \cdot 4) \\
14 \\
(17 \cdot 1) \\
31 \\
(17 \cdot 4)\end{array}$ & $\begin{array}{c}1103 \\
(19 \cdot 0) \\
11 \\
(13 \cdot 4) \\
34 \\
(19 \cdot 1)\end{array}$ & $\begin{array}{c}1325 \\
(22 \cdot 9) \\
28 \\
(34 \cdot 2) \\
62 \\
(34 \cdot 8)\end{array}$ & $\begin{array}{c}36.85 \\
P<0.001 \\
10.79 \\
0.05>P>0.02 \\
26.33 \\
P<0.001\end{array}$ \\
\hline $\begin{array}{l}72 \text { JSM staff, } 1958 \\
\text { Lateness (minutes) } \\
\text { Medical passes }\end{array}$ & $\cdots$ & $\begin{array}{r}3321 \\
(21 \cdot 5) \\
34 \\
(26 \cdot 8) \\
33 \\
(20 \cdot 0)\end{array}$ & $\begin{array}{c}3069 \\
(19 \cdot 9) \\
15 \\
(11 \cdot 8) \\
24 \\
(14 \cdot 6)\end{array}$ & $\begin{array}{r}2926 \\
(19 \cdot 0) \\
27 \\
(21 \cdot 3) \\
34 \\
(20 \cdot 6)\end{array}$ & $\begin{array}{c}2880 \\
(18 \cdot 7) \\
33 \\
(26 \cdot 0) \\
28 \\
(17 \cdot 0)\end{array}$ & $\begin{array}{c}3243 \\
(21 \cdot 0) \\
18 \\
(14 \cdot 2) \\
46 \\
(27 \cdot 9)\end{array}$ & $\begin{array}{c}47.99 \\
P<0.001 \\
11.70 \\
0.02>P>0.01 \\
8.36 \\
0.10>P>0.05\end{array}$ \\
\hline
\end{tabular}

week was measured by correlation as in Table 6 . The results (Table 11) show that the inter-day correlations for medical and works passes are of the same order as those for one-day and some two-day absences (Table 6) - if anything, values for works passes were higher; but the correlations for lateness are very large (no less than 8 of the 10 are $>0 \cdot 8$ ), indicating a marked consistency in an (average) individual's lateness record over the days of the week. These findings will be discussed later. 
TABLE 11

Correlation Coefficients (r) Between RESPECTIVELY NUMBERS OF MiNUTES LATE, Medical Passes, and Works Passes by DAy OF THE WeEk (Group G3, 1957-58)

\begin{tabular}{l|ccc}
\hline Day of the week & $\begin{array}{c}\text { Minutes } \\
\text { late }\end{array}$ & $\begin{array}{c}\text { Medical } \\
\text { passes }\end{array}$ & $\begin{array}{c}\text { Works } \\
\text { passes }\end{array}$ \\
\hline Mon./Tues. & 0.813 & 0.185 & 0.474 \\
Mon./Wed. & 0.835 & 0.439 & 0.313 \\
Mon./Thurs. & 0.856 & 0.411 & 0.421 \\
Mon./Fri. & 0.811 & 0.225 & 0.321 \\
Tues./Wed. & 0.747 & 0.135 & 0.377 \\
Tues./Thurs. & 0.845 & 0.151 & 0.605 \\
Tues./Fri. & 0.801 & 0.301 & 0.295 \\
Wed./Thurs. & 0.810 & 0.211 & 0.531 \\
Wed./Fri. & 0.798 & 0.205 & 0.311 \\
Thurs./Fri. & 0.880 & 0.049 & 0.328 \\
\hline
\end{tabular}

Maximum standard error is approximately 0.09.

\section{Association between respectively one-day absences, two-day absences, lateness and passes from work in different periods of time}

The purposes of these examinations are threefold: (a) to provide data crucial to assessing the hypotheses of causation which later come under test (Froggatt, 1970d); (b) to examine the predictive power for each variate in turn using the past record; and $(c)$ to provide information of value in judging the 'causes' of each event. One-day and two-day absences, the factors primarily under study, will be dealt with in more detail than the others, and the main analysis will be on groups from company $\mathbf{G}$.
The following notation is adopted. The number of one-day and two-day absences taken in the first period of observation are denoted respectively $m_{1}$ and $\mathrm{m}_{2}$; those taken (by the same individuals) in the second period are denoted respectively $n_{1}$ and $n_{2}$. The periods will be non-overlapping and of equal length. The first (of two) period of observation will be termed the 'preceding period'; the second will be termed the 'following period'.

\section{One-day absences}

Correlation and linear regression Values of $r$ between $m_{1}$ and $n_{1}$ for groups G1 to G8 and M1 and $\mathrm{M} 2$ are positive, of the order of 0.5 to 0.7 , and explain between approximately $20 \%$ (G1) and $50 \%$ (G2) of the total variation in either variate in terms of linear regression on the other. The significance of their differences from zero cannot be precisely tested since their generating distributions are skew, but when the calculations were repeated using the normal or nearly normal functions $\sqrt{ } \mathrm{m}_{1}$ and $\sqrt{ } \mathrm{n}_{1}$ (see Froggatt, 1967, ch. X) the values of $r$ were little affected (generally they are smaller) and $P<0.001$ throughout.

Linear regressions of the form

$$
\mathrm{N}_{1}=\mathrm{c}+\mathrm{bm}_{1} \text {, }
$$

where $N_{1}$ is a predicted value of the mean number of one-day absences taken in the following period by those who took $m_{1}$ in the preceding period, were calculated and show the regression coefficient (b) to be highly significant in each group (Table 12). Testing (G1 to G8) indicated that the regressions could be considered parallel though different in position (Table 13): an average within-group regression coefficient was therefore calculated as

TABLE 12

Correlation ANd Linear Regression Data fOR ONe-day Absences over $1957\left(\mathrm{~m}_{1}\right)$ and $1958\left(\mathrm{n}_{1}\right)$

\begin{tabular}{|c|c|c|c|c|c|}
\hline \multirow{2}{*}{ Group } & \multicolumn{2}{|c|}{$\mathrm{m}_{1}$ and $\mathrm{n}_{1}$} & \multirow{2}{*}{$\frac{\sqrt{ } \mathrm{m}_{1} \text { and } \sqrt{ } \mathrm{n}_{1}}{\mathrm{r}}$} & \multicolumn{2}{|c|}{$\begin{array}{c}\text { Estimates } \pm \text { standard errors for } \mathrm{c} \text { and } \mathrm{b} \\
\text { (untransformed units) }\end{array}$} \\
\hline & $\mathbf{r}$ & $\mathbf{t}$ & & c & $b$ \\
\hline $\begin{array}{l}\text { G1 } \\
\text { G2 } \\
\text { G3 } \\
\text { G4 } \\
\text { G5 } \\
\text { G6 } \\
\text { G7 } \\
\text { G8 }\end{array}$ & $\begin{array}{l}0.457 \\
0.693 \\
0.681 \\
0.572 \\
0.546 \\
0.688 \\
0.594 \\
0.542\end{array}$ & $\begin{array}{r}5 \cdot 42 \\
10 \cdot 83 \\
10 \cdot 02 \\
9 \cdot 86 \\
7 \cdot 58 \\
9 \cdot 30 \\
7 \cdot 82 \\
6 \cdot 61\end{array}$ & $\begin{array}{l}0.419 \\
0.594 \\
0.599 \\
0.502 \\
0.598 \\
0.535 \\
0.488 \\
0.490\end{array}$ & $\begin{array}{l}1.029 \pm 0.328 \\
0.454 \pm 0.170 \\
1.082 \pm 0.321 \\
1.131 \pm 0.225 \\
0.968 \pm 0.217 \\
1.088 \pm 0.278 \\
1.313 \pm 0.199 \\
1.153 \pm 0.242\end{array}$ & $\begin{array}{l}0.486 \pm 0.089 \\
0.659 \pm 0.062 \\
0.630 \pm 0.064 \\
0.623 \pm 0.064 \\
0.518 \pm 0.069 \\
0.662 \pm 0.073 \\
0.511 \pm 0.066 \\
0.481 \pm 0.073\end{array}$ \\
\hline $\begin{array}{l}\text { M11 } \\
\text { M2 }^{1}\end{array}$ & $\begin{array}{l}0.462 \\
0.578\end{array}$ & $\begin{array}{l}6 \cdot 16 \\
6 \cdot 35\end{array}$ & - & $\begin{array}{l}1 \cdot 213 \pm 0 \cdot 178 \\
1 \cdot 366 \pm 0.322\end{array}$ & $\begin{array}{l}0.416 \pm 0.068 \\
0.600 \pm 0.091\end{array}$ \\
\hline
\end{tabular}

${ }^{1} \mathrm{~m}_{1}=1958 ; \mathrm{n}_{1}=1959$.

All values of $r, c$, and $b$ are significant on normal theory at $\mathbf{P}=0.001$. 
TABLE 13

ANAlysis of the Regressions (G1 to G8) in Table 12

\begin{tabular}{|c|c|c|c|c|c|c|c|c|c|c|}
\hline \multicolumn{6}{|c|}{ Source of variation } & \multirow{2}{*}{$\begin{array}{r}\begin{array}{r}\text { Sum of } \\
\text { squares }\end{array} \\
2,117 \cdot 8 \\
28 \cdot 9 \\
60 \cdot 4 \\
3,386 \cdot 8\end{array}$} & \multirow{2}{*}{$\begin{array}{r}\text { D.F. } \\
1 \\
7 \\
7 \\
974\end{array}$} & \multirow{2}{*}{$\begin{array}{c}\begin{array}{c}\text { Mean } \\
\text { square }\end{array} \\
\\
4 \cdot 13 \\
8 \cdot 63 \\
3 \cdot 48\end{array}$} & \multirow{2}{*}{$\begin{array}{c}\begin{array}{c}\text { Variance } \\
\text { ratio }\end{array} \\
\\
1 \cdot 19 \\
2 \cdot 48\end{array}$} & \multirow{2}{*}{$\begin{array}{c}P \\
\substack{>0.20 \\
0.01-0.05}\end{array}$} \\
\hline $\begin{array}{l}\text { Regression } \\
\text { Difference bet } \\
\text { Distances betw } \\
\text { Residual }\end{array}$ & $\begin{array}{c}\ldots \\
\text { ween regres } \\
\text { veen regress } \\
\ldots\end{array}$ & $\begin{array}{l}\cdots \\
\text { on coefi } \\
\text { lines } \\
\ldots\end{array}$ & $\begin{array}{l}\text { ficients } \\
\ldots \\
\ldots\end{array}$ & $\begin{array}{l}\cdots \\
\cdots \\
\cdots \\
\cdots\end{array}$ & $\begin{array}{l}\ldots \\
\cdots \\
\cdots \\
\cdots\end{array}$ & & & & & \\
\hline Total & . & . & . & .. & . & $5,593 \cdot 9$ & 989 & & & \\
\hline
\end{tabular}

$\mathrm{b}=0.577 \pm 0.025 \quad(t=23.07, \quad$ D.F. $=988$, $\mathbf{P}<0.001)$ and appropriate values of $\mathrm{c}$ for each group can be easily reached. Re-calculation and testing, substituting $\sqrt{ } \mathrm{m}_{1}$ for $\mathrm{m}_{1}$ and $\sqrt{ } \mathrm{n}_{1}$ for $\mathrm{n}_{1}$, leads validly to a within-group regression coefficient of $b=0.520 \pm 0.026$ which is close to the value of 0.577 obtained using the absolute units.

To see if these relationships held also for absences unequivocally of one day, i.e., those taken on Tuesday, Wednesday, and Thursday, similar analyses to the above showed that in group G4 (the only group tested) for these three days pooled, $r=0.556$ and $b=0.605 \pm 0.066$ which are of the order of the values obtained for the five days.

Homogeneity of the inter-period correlations The relevant analysis may be considered in two parts:
(1) examining the homogeneity of the values of $r$ between periods of equal length; and (2) comparing these values for contiguous and non-contiguous years. As regards (1), the values of $r$ for one-day absences in groups G9 to G15 (G13 to 15 contain respectively those members of G5 to 7 in continuous employment over 1955-58; G9 to 12 have already been described (Froggatt, 1970b) ) for all pairs of single-year periods over 1955-58, though omitting the 'bridging' pair 1956 with 1957, are in Table 14. Transforming to $z$ and proceeding as in Snedecor $(1956$, p. 178) the null hypothesis of homogeneity is not rejected in six of the seven groups (Table 14, final column) indicating reasonable stability of $r$. Proceeding similarly with data from group M3, again omitting 'bridging' years, gives results in Table 15 and, after transforming to $\mathrm{z}$, testing for the

TABLE 14

Correlation Coefficients for Respectively the Numbers of ONe-DAY $\left(r_{1}\right)$ AND TWo-day Absences $\left(r_{2}\right)$ in All Pairs of Years omitting only 1956 with 1957

\begin{tabular}{|c|c|c|c|c|c|c|}
\hline Group & $1955 / 6$ & $1957 / 8$ & $1955 / 7$ & $1956 / 8$ & $1955 / 8$ & $\begin{array}{c}x^{2} \\
\text { (D.F. }=4)\end{array}$ \\
\hline G9 $\begin{array}{l}\mathrm{r}_{1} \\
\\
\mathrm{r}_{2}\end{array}$ & $\begin{array}{l}0.628 \\
0.362\end{array}$ & $\begin{array}{l}0.418 \\
0.468\end{array}$ & $\begin{array}{l}0.516 \\
0.410\end{array}$ & $\begin{array}{l}0.566 \\
0.456\end{array}$ & $\begin{array}{l}0 \cdot 619 \\
0 \cdot 283\end{array}$ & $\begin{array}{l}5.63 \\
1.94\end{array}$ \\
\hline $\begin{array}{r}G 10 r_{1} \\
r_{2}\end{array}$ & $\begin{array}{l}0.468 \\
0.518\end{array}$ & $\begin{array}{l}0.646 \\
0.427\end{array}$ & $\begin{array}{l}0.511 \\
0.126\end{array}$ & $\begin{array}{l}0.589 \\
0.512\end{array}$ & $\begin{array}{l}0 \cdot 383 \\
0 \cdot 192\end{array}$ & $\begin{array}{c}7.99 \\
17.09^{1}\end{array}$ \\
\hline G11 $\begin{array}{r}r_{1} \\
r_{2}\end{array}$ & $\begin{array}{l}0.670 \\
0.516\end{array}$ & $\begin{array}{l}0 \cdot 794 \\
0 \cdot 137\end{array}$ & $\begin{array}{l}0 \cdot 642 \\
0 \cdot 180\end{array}$ & $\begin{array}{l}0.650 \\
0.381\end{array}$ & $\begin{array}{l}0.560 \\
0.399\end{array}$ & $\begin{array}{l}8 \cdot 59 \\
9 \cdot 89^{2}\end{array}$ \\
\hline $\begin{array}{r}G 12 \begin{array}{r}r_{1} \\
r_{2}\end{array}\end{array}$ & $\begin{array}{l}0.695 \\
0.321\end{array}$ & $\begin{array}{l}0.585 \\
0.419\end{array}$ & $\begin{array}{l}0.521 \\
0.308\end{array}$ & $\begin{array}{l}0.488 \\
0.472\end{array}$ & $\begin{array}{l}0.501 \\
0.141\end{array}$ & $\begin{array}{r}9 \cdot 98^{2} \\
11 \cdot 23^{2}\end{array}$ \\
\hline $\begin{array}{r}G 13 r_{1} \\
r_{2}\end{array}$ & $\begin{array}{l}0.466 \\
0.483\end{array}$ & $\begin{array}{l}0.528 \\
0.313\end{array}$ & $\begin{array}{l}0.276 \\
0.230\end{array}$ & $\begin{array}{l}0.409 \\
0.494\end{array}$ & $\begin{array}{l}0 \cdot 308 \\
0 \cdot 177\end{array}$ & $\begin{array}{l}3 \cdot 32 \\
5 \cdot 72\end{array}$ \\
\hline $\begin{array}{r}\text { G14 } r_{1} \\
r_{2}\end{array}$ & $\begin{array}{l}0.676 \\
0.393\end{array}$ & $\begin{array}{l}0.755 \\
0.441\end{array}$ & $\begin{array}{l}0.513 \\
0.528\end{array}$ & $\begin{array}{l}0.528 \\
0.281\end{array}$ & $\begin{array}{l}0.547 \\
0.415\end{array}$ & $\begin{array}{l}5.93 \\
2.07\end{array}$ \\
\hline $\begin{array}{r}G 15 r_{1} \\
r_{2}\end{array}$ & $\begin{array}{l}0.635 \\
0.233\end{array}$ & $\begin{array}{l}0.581 \\
0.420\end{array}$ & $\begin{array}{l}0.552 \\
0.401\end{array}$ & $\begin{array}{l}0.488 \\
0.443\end{array}$ & $\begin{array}{l}0.337 \\
0.227\end{array}$ & $\begin{array}{l}8.48 \\
5.08\end{array}$ \\
\hline
\end{tabular}

1Significant at $\mathbf{P}=0.01$.

2Significant at $\mathbf{P}=0.05$. 
TABLE 15

Correlation Coefficients (r) and Values OF $\bar{z}$ FOR NUMBERS OF ONE-DAY ABSENCES taken by Group M3 In Pairs of Years SEPARATED BY INTERVALS OF $0,1,2$ ...... YeARS

\begin{tabular}{c|cc}
\hline Pairs of years & $\mathrm{r}$ & $\overline{\mathrm{z}}$ \\
\hline $1953 / 4$ & 0.575 & $\overline{\mathrm{z}}_{0}=0.551$ \\
$1955 / 6$ & 0.459 & \\
$1957 / 8$ & 0.463 & \\
$1953 / 5$ & 0.602 & \\
$1954 / 6$ & 0.424 & $\overline{\mathrm{z}}_{1}=0.562$ \\
$1957 / 9$ & 0.492 & \\
$1953 / 6$ & 0.258 & \\
19547 & 0.525 & $\bar{z}_{2}=0.458$ \\
$1955 / 8$ & 0.482 & \\
$1953 / 7$ & 0.533 & \\
19548 & 0.413 & $\bar{z}_{3}=0.513$ \\
$1955 / 9$ & 0.466 & \\
$1953 / 8$ & 0.365 & $\bar{z}_{4}=0.440$ \\
$1954 / 9$ & 0.459 & \\
$1953 / 9$ & 0.351 & $\mathrm{z}_{5}=0.366$ \\
\hline
\end{tabular}

homogeneity of the 15 correlations gives $\chi^{2}=12 \cdot 37$, D.F. $=14,0.70>P>0.50$ confirming the previous result.

As regards (2) above, from Table 14 the average values of $\mathrm{z}$ were calculated from the values of $\mathrm{r}$ for contiguous years 1955 with 1956 and 1957 with 1958 $\left(\bar{z}_{0}\right)$ and similarly for years separated by one year, viz., 1955 with 1957 and 1956 with $1958\left(\bar{z}_{1}\right)$, the results being tested, with the values of $\mathrm{z}$ for 1955 with $1958\left(z_{2}\right)$, for homogeneity as above. After omitting group G9 - where testing (taking the minimum significant differences at $P=0.05$ ) showed significant differences between values of $z_{0}$ precluding their valid pooling - testing as previously shows (Table 16) that the null hypothesis of homogeneity can be rejected in two of the six groups. Inspection shows the correlations to decrease as the interval between the periods increases, groups G9 and G14 being exceptions. Transforming to $z$ and repeating the examinations in group $\mathbf{M} 3$, testing within groups separated by intervals of 0,1 , $2 \ldots \ldots \ldots$ years (Table 15, col. 2) shows no significant heterogeneity for the values in any group and so an average value of $z\left(\bar{z}=\bar{z}_{0}, \bar{z}_{1} \ldots \ldots \ldots\right)$ to represent each grouping could be reached (Table 15 , col. 3). Re-testing for homogeneity of $\bar{z}_{0}, \bar{z}_{1}$ $\ldots \ldots \ldots z_{5}$ indicates that the null hypothesis is not rejected $\left(x^{2}=3.92, \mathrm{D} . \mathrm{F} .=5,0.70>\mathrm{P}>0.50\right)$
TABLE 16

Test for Homogeneity of Mean Values OF $Z$ (FROM TABLE 14) FOR RESPECTIVELY

ONE-DAY ABSENCES AND TWO-DAY ABSENCES IN Contiguous Years $\left(\bar{z}_{0}\right)$ and Years SEPARATED BY INTERVALS OF ONE $\left(z_{1}\right)$ AND Two YeARS $\left(\mathrm{z}_{2}\right)$

\begin{tabular}{|c|c|c|c|c|c|}
\hline Group & $\bar{z}_{0}$ & $z_{1}$ & $\mathbf{z}_{2}$ & $\left(D . F \cdot x^{2}=2\right)$ & $\mathbf{P}$ \\
\hline $\begin{array}{c}\text { One-day } \\
\text { G9 } \\
\text { G10 } \\
\text { G11 } \\
\text { G12 } \\
\text { G13 } \\
\text { G14 } \\
\text { G15 }\end{array}$ & $\begin{array}{l}\text { bsences } \\
0 . \overline{639} \\
0.946 \\
0.764 \\
0.546 \\
0.903 \\
0.713\end{array}$ & $\begin{array}{l}0.607 \\
0.621 \\
0.769 \\
0.556 \\
0.359 \\
0.578 \\
0.578\end{array}$ & $\begin{array}{l}0.725 \\
0.404 \\
0.633 \\
0.551 \\
0.318 \\
0.614 \\
0.351\end{array}$ & $\begin{array}{l}-1 \\
4 \cdot 02 \\
5 \cdot 52 \\
7 \cdot 36 \\
3 \cdot 17 \\
8 \cdot 07 \\
4 \cdot 24\end{array}$ & $\begin{array}{c}- \\
0.10-0 \cdot 20 \\
0.05-0 \cdot 10 \\
0 \cdot 02-0 \cdot 05 \\
0 \cdot 20-0 \cdot 30 \\
0.01-0.02 \\
0 \cdot 10-0.20\end{array}$ \\
\hline $\begin{array}{c}\text { Two-day } \\
\text { G9 } \\
\text { G10 } \\
\text { G11 } \\
\text { G12 } \\
\text { G13 } \\
\text { G14 } \\
\text { G15 }\end{array}$ & $\begin{array}{l}\text { bsences } \\
0.424 \\
0.516 \\
-\overline{395} \\
0.426 \\
0.445 \\
0.341\end{array}$ & $\begin{array}{l}0.433 \\
0.292 \\
0.416 \\
0.390 \\
0.439 \\
0.448\end{array}$ & $\begin{array}{l}0 \cdot 283 \\
0 \cdot 194 \\
0 \cdot 424 \\
0 \cdot 142 \\
0 \cdot 179 \\
0 \cdot 442 \\
0 \cdot 231\end{array}$ & $\begin{array}{l}1.37 \\
- \\
7.75 \\
2.76 \\
0.01 \\
1.63\end{array}$ & $\begin{array}{c}0.50-0.70 \\
- \\
- \\
0.02-0.05 \\
0.20-0.30 \\
>0.99 \\
0 \cdot 30-0 \cdot 50\end{array}$ \\
\hline
\end{tabular}

though inspection shows that the smallest two coefficients are $\bar{z}_{4}$ and $z_{5}$, not discordant with the company $\mathrm{G}$ results above.

The results under (1) and (2) are not completely consistent with each other, possibly because too much was asked of the statistical tests and/or values of $r$ which were not derived from independent trials were sometimes pooled. It is therefore prudent to reach only a tentative conclusion, viz., that the inter-period correlations are reasonably stable but any differences that may exist suggest that the correlations tend to decrease as the interval between the periods increases. These findings are further considered when hypotheses of causation come under test (Froggatt, 1970d).

Length of the observation periods and correlation To examine whether the length of the (equal) observation periods affects the value of the inter-period correlations, values of $r$ were obtained for group M3 which had the longest period of data available -for single-year, double-year, and treble-year periods. As in company $\mathbf{M}$, unlike company $\mathbf{G}$, the changes in marital status in male employees since enrolment were not known, it was necessary first to show that on average such changes over the trial period should not, in themselves, have affected the results and secondly to allow for effects of inter-group differ- 
ences in age and length of service structures. These were effected by a method of multiple covariance analysis (Snedecor, 1956, pp. 420-4) and a method of testing differences in adjusted means (Snedecor, 1956, p. 253). The results - set out in detail in Froggatt (1967, ch. X) - showed that, with certain minor qualifications, direct comparisons between the relevant correlation coefficients for contiguous periods and omitting 'bridging years' could be made. Using $\mathrm{z}$ transformation theory as before, the appropriate average correlation coefficients (r) are: 0.501 for contiguous single-year periods, 0.615 for contiguous double-year periods, and 0.678 for the contiguous treble-year period 1954-56 with 1957-59. Inspection strongly indicates an increase as the (equal) observation periods lengthen, and testing (Snedecor, 1956, pp. 178-9) shows that the coefficients cannot in fact be considered as samples from the same population coefficient $\left(\chi^{2}=6 \cdot 75\right.$, D.F. $=2,0.05>P>0.01)$. This is important to the hypotheses of causation - which are discussed later (Froggatt, 1970d) - and more pragmatically indicates that increasing the observational period could improve to an important extent the power of prediction for the future from past experience.

Curvilinear regression The regression of the number of one-day absences in the following period $\left(n_{1}\right)$ on that in the preceding period $\left(m_{1}\right)$ has been taken to be linear, a coherent and meaningful concept. Nevertheless, while it is difficult to understand what interpretation could be attached to higher-order regressions, it is necessary to examine whether the dependence of $n_{1}$ on $m_{1}$ could be better represented by a curve. Regressions, using the simple power series in $\mathrm{m}_{1}$, of the form

$$
\mathrm{N}_{1}=\mathrm{C}+\mathrm{B}_{1} \mathrm{~m}_{1}+\mathrm{B}_{2} \mathrm{~m}_{1}^{2}+\mathrm{B}_{3} \mathrm{~m}_{1}{ }^{3},
$$

where $B_{1}, B_{2}$, and $B_{3}$ are the partial regression coefficients, were calculated for groups $\mathrm{G} 1$ to $\mathrm{G} 8$ for 1957 and 1958 and any improvement due to quadratic and cubic terms was estimated from step-by-step testing (Quenouille, 1952, p. 95 et seq.). In only one group was any higher term significant (quadratic in group G6) and the linear effect of $m_{1}$ was always much the greatest, never accounting for less than $90 \%$ of the variation ascribable to regression. These results also held when the normally

- (or near normally) distributed variates $\sqrt{\mathrm{m}_{1}}$ and $\sqrt{n_{1}}$ were substituted for $m_{1}$ and $n_{1}$. (Complete analyses appear in Froggatt, 1967, ch. X.) Linear regression is a significant factor explaining the relationship between one-day absences taken by the same individuals in two periods of time.

Two-day absences

Correlation and linear regression The analyses were repeated for two-day absences leading to the results in Tables 17 and 18. Values of $r$ and $b$ are positive though somewhat lower than for one-day absences, and, unlike one-day absences, testing showed that the regressions of $n_{2}$ (two-day absences in 1958) on $\mathrm{m}_{2}$ (two-day absences in 1957) for groups G1 to G8 cannot be considered parallel and so no withingroup average regression coefficient can be calculated to represent the pooled groups' experience. Caution in interpretation is demanded because the distributions of $m_{2}$ and $n_{2}$ are highly skewed (negative exponential) and, unlike $m_{1}$ and $n_{1}$, not amenable to transformation to normal curves.

Testing for differences in inter-period correlations leads to the results in Tables $14\left(r_{2}\right)$ and 16 . These show rejection of the null hypothesis of homogeneity in three of the eight groups and again a suggestion, though not as marked as for one-day absences, that the correlations decrease as the interval between the periods lengthens. Unlike oneday absences, however, lengthening the (equal) observation periods has no significant effect on the inter-period correlations: for group M3 the relevant values are 0.378 for contiguous single years, 0.400 for contiguous double years, and 0.454 for the treble-year periods 1954-56 with 1957-59 though here again inspection suggests an increase as the period lengthens. The limitations to the argument are as outlined for one-day absences above, and again the results are applied later to help discriminate the hypotheses of causation (Froggatt, 1970d).

TABLE 17

CORRELATION AND LiNeAR Regression DATA FOR TWO-DAY ABSENCES OVER $1957\left(\mathrm{~m}_{2}\right)$ AND $1958\left(\mathrm{n}_{2}\right)$

\begin{tabular}{|c|c|c|c|c|}
\hline \multirow[t]{2}{*}{ Group } & \multirow[t]{2}{*}{$\mathbf{r}$} & \multirow[t]{2}{*}{$\mathbf{t}$} & \multicolumn{2}{|c|}{$\begin{array}{c}\text { Estimates } \pm \text { standard errors } \\
\mathrm{c} \text { and } \mathrm{b}\end{array}$} \\
\hline & & & c & b \\
\hline $\begin{array}{l}\text { G1 } \\
\text { G2 } \\
\text { G3 } \\
\text { G4 } \\
\text { G5 } \\
\text { G6 } \\
\text { G7 } \\
\text { G8 }\end{array}$ & $\begin{array}{l}0.430 \\
0.495 \\
0.247 \\
0.400 \\
0.424 \\
0.563 \\
0.438 \\
0.262\end{array}$ & $\begin{array}{l}5 \cdot 12 \\
6 \cdot 35 \\
2 \cdot 71 \\
6 \cdot 25 \\
5 \cdot 44 \\
6 \cdot 55 \\
5 \cdot 09 \\
2 \cdot 79\end{array}$ & $\begin{array}{l}0.291 \pm 0.115 \\
0.199 \pm 0.080 \\
0.764 \pm 0.143 \\
0.707 \pm 0.100 \\
0.444 \pm 0.136 \\
0.327 \pm 0.118 \\
0.434 \pm 0.121 \\
0.598 \pm 0.132\end{array}$ & $\begin{array}{l}0.462 \pm 0.093 \\
0.761 \pm 0.119 \\
0.224 \pm 0.083 \\
0.358 \pm 0.060 \\
0.488 \pm 0.092 \\
0.437 \pm 0.067 \\
0.413 \pm 0.081 \\
0.258 \pm 0.095\end{array}$ \\
\hline $\begin{array}{l}\mathbf{M}^{1} \\
\mathbf{M}^{1}\end{array}$ & $\begin{array}{l}0.331 \\
0.334\end{array}$ & $\begin{array}{l}4 \cdot 36 \\
3 \cdot 41\end{array}$ & $\begin{array}{l}0.344 \pm 0.106 \\
0.476 \pm 0.163\end{array}$ & $\begin{array}{l}0.372 \pm 0.084 \\
0.352 \pm 0.099\end{array}$ \\
\hline
\end{tabular}

${ }^{1} \mathrm{~m}_{2}=1958 ; \mathrm{n}_{2}=1959$.

Most values of $r, c$, and $b$ are significant on normal theory at $\mathbf{P}=0.001$; all others at $\mathbf{P}=0.01$. 
TABLE 18

ANAlysis of the Regressions in TABle 17 (Groups G1 To G8)

\begin{tabular}{|c|c|c|c|c|c|c|c|c|c|}
\hline \multicolumn{5}{|c|}{ Source of variation } & \multirow{2}{*}{$\begin{array}{r}\text { Sum of } \\
\text { squares }\end{array}$} & \multirow{2}{*}{$\begin{array}{r}\text { D.F. } \\
\begin{array}{r}1 \\
7\end{array}\end{array}$} & \multirow{2}{*}{$\begin{array}{r}\begin{array}{c}\text { Mean } \\
\text { square }\end{array} \\
180 \cdot 54 \\
2.42\end{array}$} & \multirow{2}{*}{$\begin{array}{c}\begin{array}{c}\text { Variance } \\
\text { ratio }\end{array} \\
\overline{2 \cdot 44}\end{array}$} & \multirow{2}{*}{$\frac{P}{0.01-0.05}$} \\
\hline $\begin{array}{l}\text { Overall regression } \\
\text { Difference between } r\end{array}$ & gression & coefficients & & $\begin{array}{l}\cdots \\
\cdots\end{array}$ & & & & & \\
\hline $\begin{array}{l}\text { Sum of regressions } \\
\text { Residual }\end{array}$ & $\begin{array}{l}. \\
. .\end{array}$ & $\begin{array}{l}\cdots \\
\cdots\end{array}$ & $\begin{array}{l}\cdots \\
\cdots\end{array}$ & $\begin{array}{l}\cdots \\
\cdots\end{array}$ & $\begin{array}{l}197 \cdot 4 \\
964 \cdot 6\end{array}$ & $\begin{array}{r}8 \\
974\end{array}$ & $\begin{array}{r}24.68 \\
0.99\end{array}$ & & \\
\hline Total & .. & . & .. & . & $1,162 \cdot 0$ & 982 & & & \\
\hline
\end{tabular}

Curvilinear regression Testing in group G12 $\left(m_{2}=1955-56, n_{2}=1957-58\right)$ for improvement due to any quadratic effect shows that in a regression which accounts for $28 \%$ of the total variation in $n_{2}$ as little as $0.01 \%$ is ascribable to the quadratic term. Linear regression is therefore again a significant factor explaining the relationship between two-day absences in two periods of time.

\section{Lateness and passes from work}

Inter-period correlation coefficients for lateness (G1 to G8) and numbers of medical and works passes (G3 and G5) are set out in Table 19. All are positive and (on normal theory) significant. The values for lateness, either 'occasions late' or 'minutes late', and for works passes are very substantial and are in fact the highest for any variates considered in this study. The generating distributions are skewed generally with an excess of observations in the zero frequency class and a long 'positive' tail, but on the experience of the previous paper (Froggatt, 1970b), and of the above, transforming them to more symmetrical functions should not substantially affect the results.

\section{TABLE 19}

Correlation Coefficients \pm Standard ERRORS BETWEEN RESPECTIVELY LATENESS, Medical Passes, and Works Passes taken IN 1957 AND 1958

\begin{tabular}{c|ccc}
\hline Group & Lateness $^{1}$ & Medical passes & Works passes \\
\hline G1 & $0.819 \pm 0.054$ & & \\
G2 & $0.837 \pm 0.050$ & & \\
G3 & $0.771 \pm 0.059$ & $0.389 \pm 0.086$ & $0.629 \pm 0.073$ \\
G4 & $0.704 \pm 0.051$ & & \\
G5 & $0.859 \pm 0.045$ & $0.179 \pm 0.087$ & $0.714 \pm 0.044$ \\
G6 & $0.799 \pm 0.063$ & & \\
G7 & $0.852 \pm 0.050$ & & \\
G8 & $0.826 \pm 0.055$ & & \\
\hline
\end{tabular}

1'Occasions late' for G1 and G2; 'minutes late' for other groups.

\section{Discussion}

The approach adopted necessitates examining the associations, with short-term absences, of as many recorded variables as possible in order to elucidate the genesis of the events. This paper gives the results of these and related analyses, but for coherent presentation their discussion is reserved for the final paper (Froggatt, 1970d) where the complete findings and arguments are set out in detail. Only results which are not subsequently elaborated are discussed here: these relate to the interpretation of the associations between, respectively, lateness, medical passes, and works passes taken by the same individuals in two periods of time.

Table 11 shows a very high consistency in lateness experience by day of week, and Table 19 similarly by year of observation: in fact the values of $r$ obtained (no less than 13 of the 18 presented are greater than $0 \cdot 80$, as are many of those estimated but not presented) are among the highest recorded for events involving human behaviour. This indicates that lateness is a highly 'predictable' phenomenon and, therefore, in the context largely preventable - though the disruption to work and morale due to such (consistent) lateness may well be unimportant. The decrease in lateness with age, found also by Taylor (1967a), may be a 'survivor' or cohort phenomenon; if not, it could indicate the development of, say, a stronger discipline with advancing years. One-day absences also decrease with age (Froggatt, 1970b), as was also generally found by Kahne et al. (1957) and by Taylor (1967a) for day workers, which could be similarly interpreted and the consistent independent association between lateness and one-day absences (Table 2 - values of $b_{3}$ ) sustains the contention that there may be 'causes' common to both.

Inter-day and inter-year correlations for works passes and medical passes (Tables 11 and 19) are lower than for lateness, and those for medical passes are often insignificant. Medical passes in fact are largely 'unpredictable'; works passes are less so though seldom is more than $20 \%$ of the variation in 
any day-of-the-week's experience explicable in terms of linear regression on that of any other day. The order of the inter-period correlations for works passes and for one-day absences is similar - as is the suspicion of a mutual subsidiary Wednesday peak (for males); yet these two events are either very weakly correlated (Froggatt, 1967, ch. V) or in some groups even unrelated (Table 2), suggesting that any common factors of causation are unremarkable, and unlike one-day absences works passes are independent of age. In fact, the evidence of daily variation suggests that the two may on occasions complement rather than parallel each other; thus the Friday nadir of one-day absences (Table 4) was balanced to some extent by a Friday peak of works passes (Tables 9 and 10), suggesting that early leaving rather than a day's absence was the method favoured for a premature start to the week-end. By similar inference, two-day absences and medical passes share certain characteristics, but their daily and seasonal patterns seem unrelated and in fact Table 3 shows them to be independent phenomena. Thus, while consideration of the results gives useful information to any study of short-term absences, the conclusions drawn are seldom unequivocal. These are considered further when discussing 'causes' after the hypotheses of causation have come under test (Froggatt, 1970d).

The references for this paper will appear at the end of Part III in the October 1970 issue of the Journal.

Received for publication October 13, 1969 